\title{
Vines in Florida Citrus ${ }^{1}$
}

\section{Stephen H. Futch ${ }^{2}$}

Numerous vine weed species can be found in Florida citrus groves. Frequently found vines include: milkweed (Fig. 1), balsam-apple (Fig. 2), possum grape, Virginia creeper, morning-glory, cats-claw, and skunk vine. In addition to the above species, other vines may be present, or some broadleaf weeds (i.e. phaseybean) may become vine-like and emerge from the upper canopy area of citrus trees.

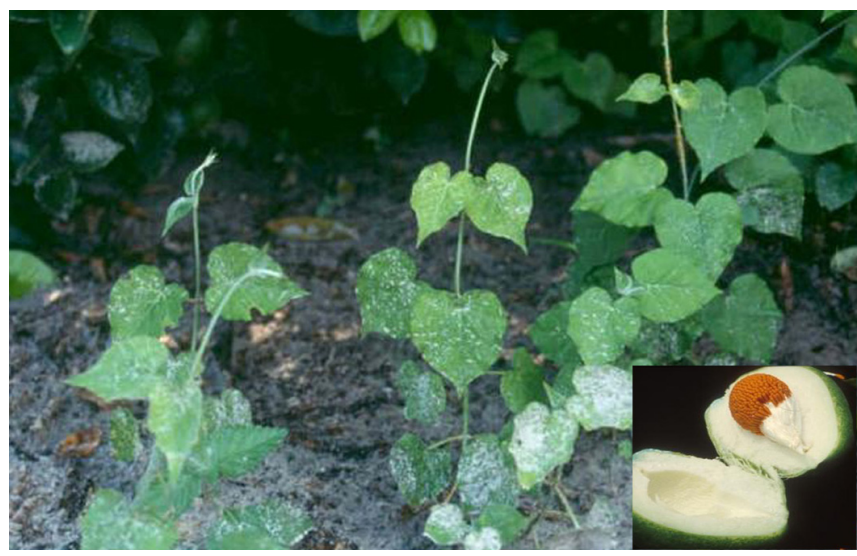

Figure 1. Milkweed vine.

Vines are broadleaf weeds that compete with the citrus tree for water, nutrients, space, and light. Additionally, vines may impede harvesting operations by making it difficult for harvesters to find the fruit when the canopy is covered with vines.

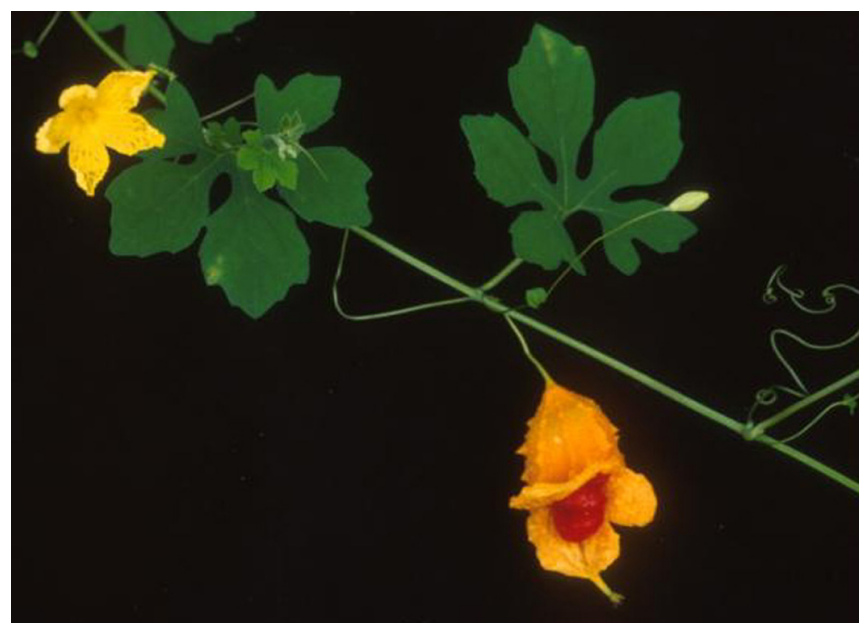

Figure 2. Balsam-apple vine.

Vines found in citrus groves are either annual or perennial. Annual vines complete their life cycle in one growing season or within 12 months, whereas perennial vines will live for two or more years. The vines can be further divided into either woody or herbaceous (non-woody) plants based upon stem characteristics.

1. This document is HS1063, one of a series of the Horticultural Sciences Department, Florida Cooperative Extension Service, Institute of Food and Agricultural Sciences, University of Florida. Original publication date June, 2007. Visit the EDIS Web Site at http://edis.ifas.ufl.edu.

2. S.H. Futch, extension agent IV, Horticultural Sciences Department, Citrus REC, Lake Alfred, Florida; Cooperative Extension Service, Institute of Food and Agricultural Sciences, University of Florida, Gainesville, 32611

The use of trade names in this publication is solely for the purpose of providing specific information. UF/IFAS does not guarantee or warranty the products named, and references to them in this publication does not signify our approval to the exclusion of other products of suitable composition. All chemicals should be used in accordance with directions on the manufacturer's label.

The Institute of Food and Agricultural Sciences (IFAS) is an Equal Opportunity Institution authorized to provide research, educational information and other services only to individuals and institutions that function with non-discrimination with respect to race, creed, color, religion, age, disability, sex, sexual orientation, marital status, national origin, political opinions or affiliations. U.S. Department of Agriculture, Cooperative Extension Service, University of Florida, IFAS, Florida A. \& M. University Cooperative Extension Program, and Boards of County Commissioners Cooperating. Larry Arrington, Dean 
Vines have the unique ability to germinate and grow in areas where light levels are reduced by shading of the tree canopy. This shading reduces the germination and growth of a number of other weed species, but is usually not a limiting factor for vines. Vine stems elongate and reach the lower limbs of the tree, which allows growth into the upper canopy. Some vines will climb, lean on, coil around, or attach to the tree branches using special stem modifications, which are referred to as tendrils. These tendrils actually attach to the host plant, providing the necessary support for the vine's upward growth. In other cases, the vine may have adventitious roots on the stem that attach the vine to the tree, walls, or other places where it is growing. Once in the upper canopy, vines flourish, grow, and produce seeds for new populations and added reproduction. The seeds of some vine species can attract wildlife with vivid seed color (balsam-apple, possum grape vine) to aid in seed distribution. Other species (milkweed vine) seeds are dispersed and carried in the air. Their fine, hair-like attachments improve aerodynamics and serve as sails or parachutes to aid in seed dissemination by the air to new locations. Seed numbers vary from a few seeds (skunk vine) to hundreds of seeds (milkweed vine) per pod.

Once vines are well established in the tree canopy, control with pre- or postemergence herbicide products becomes increasingly more difficult. This increased difficulty is due to a number of factors including: 1) large plant mass requires higher herbicide application rates; 2 ) inability to reach vine leaves with contact or translocated herbicides to obtain adequate absorption and insure vine death; and 3) lower stems do not readily absorb postemergence products (glyphosate) in sufficient quantity to kill stems of the hardened plant stem.

When vines are well established in the upper tree canopy, hand labor is required to aid in vine control. Hand labor can sever the vine stems or pull them from the tree canopy and allow them to lie on the soil surface. There they can be treated with postemergence products or allowed to slightly regrow and then be treated with herbicides before becoming re-entangled into the tree canopy.
The exception to the above procedure is possum grape vine (Fig. 3). When its stems are severed, they can develop aerial roots which then grow into the soil surface and root, allowing the vine to continue to grow and flourish.

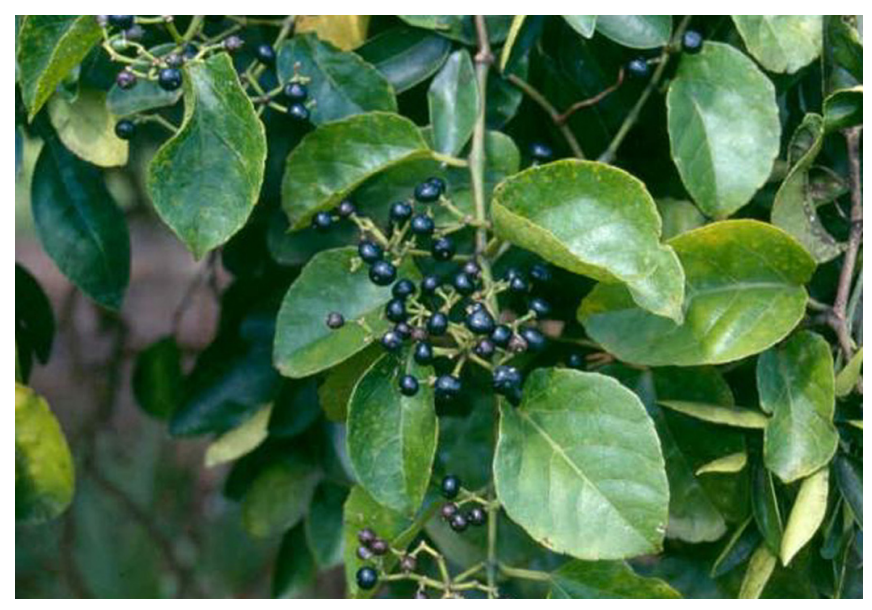

Figure 3. Possum grape vine.

\section{Vine Control}

One of the first steps in controlling any vine or weed species is proper identification to aid in the selection of control strategies. Factors that aid in the identification process of weeds or vine species involve a combination of leaf, stem, fruit, and/or seed characteristics. For description and photos of vines found in citrus, please view "Identification of Vine Weeds in Florida Citrus" at http://edis.ifas.ufl.edu/HS185. Other weeds are also identified at the EDIS web site or available in print in "Identification of Weeds in Florida Citrus", SP 341 from the University of Florida by calling 1-800-226-1764 or on the web at http://www.ifasbooks.ufl.edu.

Citrus growers have several approaches to suppress and/or control vines within groves. These options include prevention along with mechanical and chemical control. Each chosen practice will vary with location, soil type, time (season), tree spacing and age, vine presence, cost, and grower preference.

Preventative programs should be one of the first control strategies. This includes practices of sanitation, spot spraying, and the use of hand labor to prevent vines from widespread dissemination into the grove from limited infestation areas or from adjoining properties. While these practices may not 
completely stop the spread of undesirable weed or vine species, they may slow the spread over time, thus reducing total management costs.

Mechanical control was more frequently used in the past when tillage equipment was placed under the tree canopy in an effort to sever the stems and roots of weeds or vines. Tillage use has decreased in recent years since more groves are planted on raised beds and tillage increases the chances of soil erosion to occur. Tillage also damages fibrous roots close to the soil surface, or may damage the low volume irrigation system tubing or emitters.

Chemical control utilizes the application of herbicides which are either soil-applied preemergence herbicides or foliar applied postemergence herbicides which are sprayed onto the weed leaf surface (Table 1). Preemergence herbicides should be applied to soil that is somewhat free of weeds to allow for complete coverage of the soil surface. If weeds are present, postemergence herbicides should be applied in combination with the preemergence herbicides to not only kill the emerged weeds but to provide future weed control.
To effectively control vines, growers should apply preemergence herbicides prior to seed emergence or during early seedling stages when applied in combination with postemergence products. Postemergence herbicides can be applied when the vines are still short and not entangled into the tree canopy.

\section{Conclusion}

Growers need to consider all management options to limit vine growth. Early detection and control when vines are limited to isolated areas in the grove or adjacent property is very important. Once vines are present in the grove, chemical control is the most frequently chosen control method.

Table 1. Pre- and Postemergence Herbicides Recommended for Vine Control.

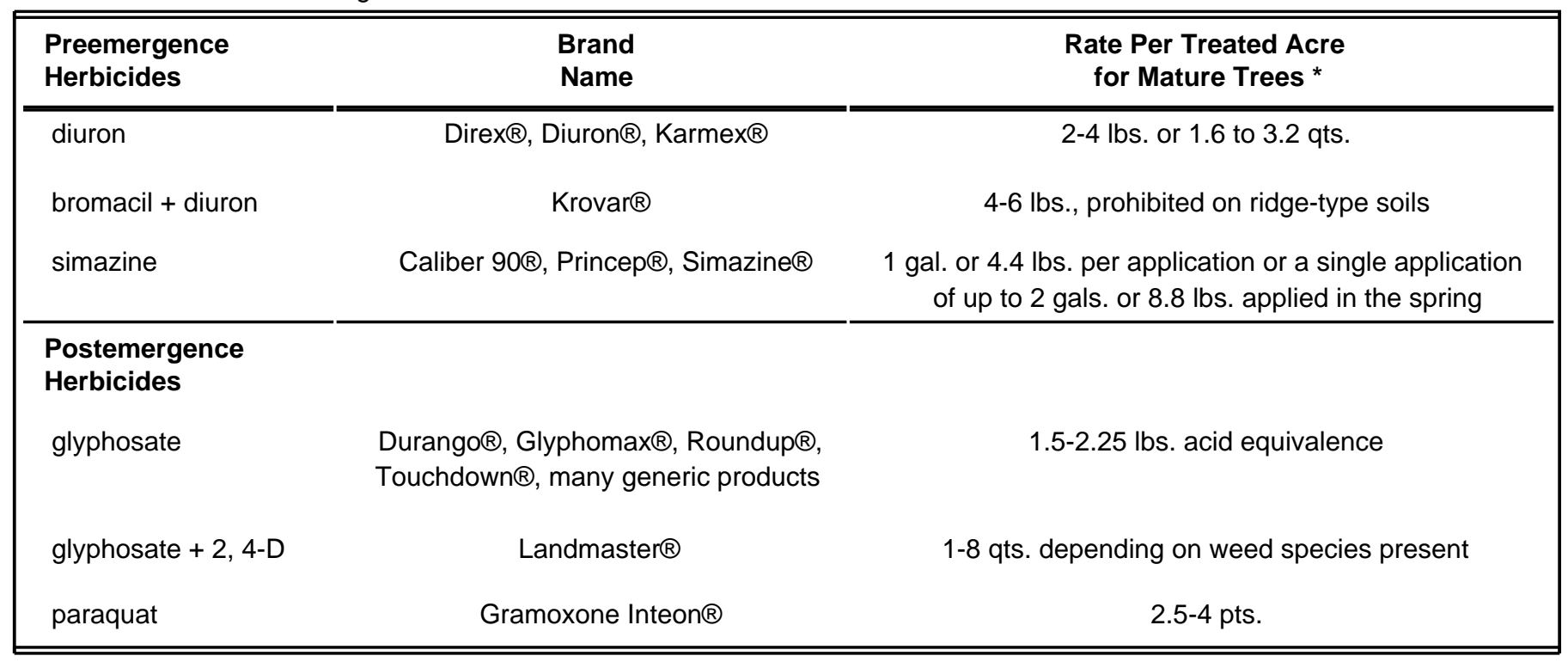

